\title{
Dilematis Hukum Mahkamah Konstitusi dalam Perspektif Putusan
}

\author{
Achmad Rubaie \\ Fakultas Hukum, Universitas dr. Soetomo, Surabaya. \\ Email : ach.rubaie02@gmail.com
}

\section{Info Artikel:}

\begin{abstract}
In its development, demands for amendments or changes to the 1945 Constitution of the Republic of Indonesia eventually became a common need of the Indonesian people. Furthermore, the demand was realized in a comprehensive, gradual and systematic manner in four changes through the mechanism of the special session of the People's Consultative Assembly (MPR) from 1999 to 2002. This research is normative legal research, namely legal research which focuses on legal review or study positive. In accordance with the scientific character of normative law, the study of positive laws includes the study of legal dogmatism, review of legal theory, and review of legal philosophy. From the review of several decisions of the Constitutional Court (MK) which are ultra petita, it was found that in making decisions on cases filed with the Constitutional Court, both relating to Judicial Review and settlement of electoral disputes. Theoretically, the Constitutional Court Judge, in his consideration, is more inclined to use the type of interpretation of the contextualization of the original values from the type of textual interpretation or interpretation of originalism, so that the Constitutional Court judge's discretionary space is wide open, which results in distorting legislative authority. , especially in the case of judges creating and formulating new norms.
\end{abstract}

Keywords: Legal Dilemma, Constitutional Court Decision, Constitutional Law.

\begin{abstract}
Abstrak
Dalam perkembangannya, tuntutan amandemen atau perubahan Undang-Undang Dasar Negara Republik Indonesia 1945 pada akhirnya menjadi kebutuhan bersama bangsa Indonesia. Selanjutnya, tuntutan itu diwujudkan secara komprehensif, bertahap dan sistematis dalam empat kali perubahan melalui mekanisme sidang istimewa Majelis Permusyawaratan Rakyat (MPR) sejak tahun 1999 sampai dengan tahun 2002. Penelitian ini merupakan penelitian hukum normatif, yaitu penelitian hukum yang menitikberatkan pada telaah atau kajian hukum positif. Sesuai dengan karakter keilmuan hukum normatif, maka telaah hukum positif tersebut meliputi telaah dogmatika hukum, telaah teori hukum, dan telaah filsafat hukum. Dari telaah beberapa putusan Mahkamah Konstitusi (MK) bersifat ultra petita, ditemukan bahwa dalam pengambilan putusan atas perkara yang diajukan kepada Mahkamah Konstitusi, baik berkaitan dengan Judicial Review maupun penyelesaian sengketa pemilihan umum. Secara teoritis Hakim MK dalam pertimbangannya, lebih condong menggunakan jenis penafsiran Kontekstualisasi nilai-nilai dasar (non original intent) dari pada jenis penafsiran tekstual atau penafsiran originalisme (original intent), sehingga terbuka ruang diskresi hakim Mahkamah Konstitusi begitu luas, yang berakibat mendistorsi kewenangan legislatif, terutama dalam hal hakim menciptakan dan merumuskan norma baru.
\end{abstract}

Kata Kunci: Dilematis Hukum, Putusan Mahkamah Konstitusi, Hukum Tata Negara. 


\section{A. PENDAHULUAN}

Runtuhnya rezim orde baru yang ditandai dengan mundurnya Presiden Republik Indonesia yang kedua, menandai awal dari era reformasi yang diinginkan oleh kelompok masyarakat dan mahasiswa pada tahun 1998. Tuntutan amandemen atau perubahan Undang Undang Dasar Negara Republik Indonesia Tahun 1945, selanjutnya disingkat UUD NRI 1945, pada era reformasi tersebut merupakan suatu langkah terobosan yang fundamental, karena pada era sebelumnya tidak dikehendaki adanya perubahan terhadap UUD NRI 1945. Dalam perkembangannya, tuntutan amandemen atau perubahan UUD NRI 1945 pada akhirnya menjadi kebutuhan bersama bangsa Indonesia. Selanjutnya, tuntutan itu diwujudkan secara komprehensif, bertahap dan sistematis dalam empat kali perubahan UUD NRI 1945 melalui mekanisme empat kali sidang Mejelis Permusyawaratan Rakyat (MPR) sejak tahun 1999 sampai dengan tahun 2002. ${ }^{1}$

Seiring dengan momentum perubahan UUD NRI 1945 pada masa reformasi, gagasan pembentukan Mahkamah Konstitusi di Indonesia semakin menguat. Puncaknya terjadi pada tahun 2002 ketika gagasan pembentukan Mahkamah Konstitusi dimasukkan dalam perubahan UUD NRI 1945 yang dilakukan oleh MPR sebagaimana dirumuskan dalam ketentuan Pasal 24 ayat (2) UUD NRI 1945 dalam Perubahan Ketiga. ${ }^{2}$ Di dalam Pasal 24 ayat (2) Perubahan Ketiga UUD NRI 1945 yang ditetapkan MPR pada 9 Nopember 2001, menambahkan lembaga pelaksanaan kekuasaan kehakiman baru,

${ }^{1}$ Perubahan Pertama sebanyak 9 (sembilan) pasal, ditetapkan Majelis Permusyawaratan Rakyat (disingkat MPR) pada tanggal 19 Oktober 1999, Perubahan Kedua sebanyak 37 (tiga puluh tujuh) pasal, ditetapkan MPR pada 18 Agustus 2000, Perubahan Ketiga sebanyak 23 (dua puluh tiga) pasal, ditetapkan MPR pada tanggal 9 Nopember 2001, dan Perubahan Keempat sebanyak 18 (delapan belas) pasal, ditetapkan MPR pada tanggal 10 Agustus 2002. hlm. 6-7.

${ }^{2}$ Sekretariat Jenderal dan Kepaniteraan Mahkamah Konstitusi, Profil Mahkamah Konstitusi Republik Indonesia, Cetakan Pertama, Jakarta Oktober 2010, hlm. 3. yakni Mahkamah Konstitusi (selanjutnya disingkat MK).

Untuk merinci dan menindaklanjuti amanat Pasal 24 ayat (2) UUD NRI 1945 tersebut, Pemerintah bersama Dewan Perwakilan Rakyat (DPR) membahas Rancangan Undang Undang (RUU) tentang Mahkamah Konstitusi. Setelah pembahasan dilakukan dengan mekanisme konstitusional dalam beberapa waktu lamanya, akhirnya RUU tentang Mahkamah Konstitusi tersebut disetujui bersama oleh Pemerintah dan DPR, dan kemudian disahkan dalam Sidang Paripurna pada tanggal 13 Agustus 2003. Pada hari dan tanggal itu juga, Undang Undang tentang Mahkamah Konstitusi ditandatangani oleh Presiden Megawati Soekarno Putri, dan diberi Nomor Undang Undang Nomor 24 Tahun 2003 tentang Mahkamah Konstitusi, dimuat dalam Lembaran Negara Tahun 2003 Nomor 98, Tambahan Lembaran Negara Nomor 4316.

Mengenai kedudukan MK dalam sistem ketatanegaraan Indonesia sebagai lembaga negara baru, dalam UUD NRI 1945 diberikan kedudukan yang sejajar dengan lembagalembaga negara lainnya, tanpa mempertimbangkan lagi adanya kualifikasi sebagai lembaga negara tertinggi atau tinggi. Lembaga-lembaga negara dimaksud meliputi Dewan Perwakilan Rakyat (DPR), Presiden, Dewan Perwakilan Daerah (DPD), Badan Pemeriksa Keuangan (BPK), Majelis Permusyawaratan Rakyat (MPR), Mahkamah Agung (MA), satu sama lain memiliki kedudukan sejajar, namun dibedakan tugas dan wewenangnya sebagaimana diatur dalam UUD NRI $1945 .^{3}$

Jika dikaji secara seksama kedudukan, kewenangan dan kewajiban MK sebagaimana dirumuskan dalam Perubahan Ketiga UUD

${ }^{3}$ Moh. Mahfud M.D, Kedudukan dan Fungsi Mahkamah Konstitusi Dalam Sistem Ketatanegaraan Republik Indonesia, Makalah disampaikan pada orientasi dalam Rangka pelantikan Anggota DPR RI dan DPD DR periode 2009-2014, yang diselenggarakan oleh Komisl Pemilihan umum, Selasa, 29 September 2009 di hotel Borobudor, Jakarta, hlm 9. 
NRI 1945 dan mengacu pada teori dan praktek mengenai MK di berbagai belahan dunia, diketahui bahwa MK memiliki 4 (empat) fungsi utama, sebagai berikut:

1. Mahkamah Konstitusi berfungsi sebagai lembaga pengawal atau penjaga konstitusi (the guardian of the constitution $)^{4}$

2. Mahkamah Konstitusi berfungsi sebagai lembaga penafsir tunggal konstitusi (the sole interpreter of the constitution) ${ }^{5}$

3. Mahkamah Konstitusi berfungsi sebagai pengawal demokrasi (the guardian of democracy). ${ }^{6}$

4. Mahkamah Konstitusi berfungsi sebagai pelindung hak konstitusional warga negara (the protector of citizen's constitutional rights) dan pelindung hak asasi manusia (the protector of human rights). ${ }^{7}$

Lebih lanjut, fungsi MK dikatakan sebagai implementasi dari fungsi pengawal demokrasi (the guardian of democracy), karena konstitusi menjadi hukum tertinggi yang mengatur penyelenggaraan negara berdasarkan prinsip-prinsip demokrasi, dalam hal ini MK mempunyai fungsi menegakkan prinsip-prinsip negara demokrasi yang tercantum dalam konstitusi melalui putusanputusannya. $^{8}$

Mengingat pentingnya fungsi MK seperti terurai di atas, maka sudah sepatutnya apabila mayoritas masyarakat Indonesia menaruh harapan besar untuk dapat ditegakkan keempat fungsi tersebut dalam praktek penyelenggaraan negara atau penegakan hukum melalui peradilan ketatanegaraan, sehingga dalam waktu yang

${ }^{4}$ Abdul Mukthie Fadjar,"Mahkamah Konstitusi sebagai pengawal dan penafsir Konstitusi: Masalah dan Tantangan", dalam Konstitusionalisme Demokrasi, inTRANS Publishing, Malang, 2010, hlm 1.

${ }^{5}$ Ibid. hlm 1

${ }^{6}$ Mahfud MD, Peran Mahkamah Konstitusi dalam Mengawal Hak Konstitusional Warga Negara, diakses dari http://www.mahfudmd.com/public/makalah/

Makalah_21.pdf.

${ }^{7}$ Ibid.

${ }^{8}$ Ibid, hlm vi. tidak terlalu lama, dapat diwujudkan visi dan misi MK RI. Adapun visi MK adalah tegaknya konstitusi dalam rangka mewujudkan cita negara hukum dan demokrasi demi kehidupan kebangsaan dan kenegaraan yang bermartabat, ${ }^{9}$ sedangkan misi MK adalah mewujudkan MK sebagai salah satu pelaku kekuasaan kehakiman yang modern dan terpercaya serta membangun konstitusionalitas Indonesia dan budaya sadar berkonstitusi. ${ }^{10}$

Berikutnya, kewenangan MK dalam memutus Sengketa Kewenangan Konstitusional Lembaga Negara (SKLN), berfungsi memberikan proteksi agar institusi negara yang dioperasionalkan oleh lembagalembaga negara dijalankan di atas rel konstitusi. Sengketa kewenangan konstitusional lembaga negara (SKLN) adalah perbedaan pendapat yang disertai persengketaan dan klaim lainnya mengenai kewenangan yang dimiliki oleh masingmasing lembaga negara tersebut. Hal ini sangat mungkin terjadi mengingat sistem relasi antara satu lembaga dengan lembaga lainnya menganut prinsip checks and balances, yang berarti sederajat tetapi saling mengawasi satu sama lain secara berkeseimbangan. ${ }^{11}$

Mahkamah Konstitusi juga diberi wewenang memutus perselisihan hasil pemilihan umum (PHPU). Pemilihan umum merupakan sarana utama pembentukan dan penyelenggaraan pemerintahan dari, oleh dan untuk rakyat (government from the people, by the people, and for the people). Oleh karena itu pemilihan umum harus dilaksanakan dengan cara yang jujur, adil, langsung, umum, bebas, rahasia dan transparan. Tidak boleh ada lagi suara pemilih yang tidak dihitung atau dimanipulasi, karena hal tersebut sama saja halnya dengan menyelewengkan kedaulatan rakyat (people's sovereignity).

${ }^{9}$ Sekretariat Jenderal dan Kepaniteraan Mahkamah Konstitusi, Profil Mahkamah Konstitusi Republik Indonesia, Jakarta, Cetakan Pertama, Oktober 2010, hlm 14.

${ }^{10}$ Ibid . hlm 14

${ }^{11}$ Ibid. hlm 10-11. 
Dalam perkara perselisihan hasil pemilu, wewenang Mahkamah Konstitusi bukan sekedar menghitung perselisihan suara saja, tetapi wajib mencari keadilan atas pelanggaran prinsip-prinsip pemilu yang demokratis, MK memang tidak diperkenankan mengadili pelanggaran pemilu yang bersifat pidana dan administratif, karena bukan menjadi kewenangan yang dimilikinya. Namun, ketika melihat adanya prinsip-prinsip pemilu yang dilanggar, sehingga menyebabkan timpangnya keadilan dalam pelaksanaan pemilu, maka MK secara hatihati dan selektif akan mengadilinya. ${ }^{12}$

Berdasarkan hasil penelusuran kepustakaan, dalam Black's Law Dictionary ditemukan istilah "substansial justice" yang diartikan sebagai: " justice administered according to the rules of substantive law, not with standing errors of procedure" 13 (keadilan yang dilaksanakan menurut hukum substantif, dengan tidak melihat kesalahankesalahan secara prosedural). Sedangkan yang dimaksud dengan "substantive law is that part of law which creates, defines, dan regulates rights, as opposed to adjective or remedial law, which prescribes method of enforcing the rights or obtaining redress for their invasion"14 (hukum substantif adalah bagian hukum yang menciptakan, menentukan dan mengatur berbagai macam hak, sebagaimana sering dilawankan dengan hukum ajektif, yaitu hukum yang mengatur cara bagaimana menegakkan hak-hak yang diatur dalam hukum substantif).

\section{B. METODE PENELITIAN}

Penelitian ini merupakan penelitian hukum normatif, yaitu penelitian hukum yang menitikberatkan pada telaah atau kajian hukum positif. Sesuai dengan karakter keilmuan hukum normatif, maka telaah hukum positif tersebut meliputi telaah dogmatika hukum, telaah teori hukum, dan

\footnotetext{
${ }^{12}$ Ibid. hlm 11-12.

${ }^{13}$ Henry Campbell Black, Black's Law Dictionary, ST Paul Minn, West Publishing Co, 1979, page 1281

${ }^{14}$ Ibid. hlm 1281.
}

telaah filsafat hukum. Menurut D.H.M. Meuwissen telaah hukum positif ini dicirikan dengan: a). sifat empiris analitis, yaitu memberikan pemaparan dan menganalisis tentang isi dan struktur hukum; b). mensistematisasi gejala-gejala hukum; c). menginterpretasi atau menafsirkan hukum yang positif; d). menilai hukum positif, dan e). secara praktis dari ilmu hukum yang berkaitan erat dengan dimensi normatif.

\section{KERANGKA KONSEPTUAL}

Pada tataran dogmatika hukum titikberat dilakukan terhadap identifikasi beberapa peraturan perundang-undangan yang terkait dengan kewenangan MK, sedangkan pada tataran teori hukum dilakukan telaah terhadap teori-teori yang dapat digunakan untuk menganalisis kewenangan MK dalam mengeluarkan putusan bersifat ultra petita, antara lain Teori Pemisahan Kekuasaan dan Teori Peran dan Tugas Hakim. Dari segi filsafat hukum pengkajiannya dititikberatkan pada relevansi keberadaan penggunaan kewenangan MK mengeluarkan putusan bersifat ultra petita, sebagai penyelenggara peradilan guna menegakkan hukum dan keadilan, serta dalam konteks dan spektrum yang luas dikaitkan dengan dianutnya prinsipprinsip negara hukum demokratis dalam UUD NRI 1945, asas peradilan yang merdeka, bebas dan tidak memihak, serta asas-asas umum penyelengaraan negara yang baik.

\section{PEMBAHASAN}

Bahwa dasar yang dipergunakan oleh MK mengeluarkan putusan bersifat ultra petita adalah hasil interpretasi atas pasal 24 ayat (1) UUD NRI 1945 : "kekuasaan kehakiman merupakan kekuasaan yang merdeka untuk menyelenggarakan peradilan guna menegakan hukum dan keadilan" dan Pasal 45 ayat (1) UU No. 24 Tahun 2003 Tentang Mahkamah Konstitusi : "Mahkamah Konstitusi memutus perkara berdasarkan undang Undang Dasar Negara Republik Indonesia Tahun 1945 sesuai alat bukti dan keyakinan hakim". Kata menegakkan 
"keadilan" dan "keadilan sesuai alat bukti dan keyakinan hakim" tersebut dipahami sebagai keadilan substantif. Dalam rangka mencapai keadilan subtanstif tersebut, maka MK mengeluarkan putusan bersifat ultra petita.

Dari telaah beberapa putusan MK bersifat ultra petita, ditemukan bahwa dalam pengambilan putusan atas perkara yang diajukan kepada MK, baik berkaitan dengan judicial review maupun penyelesaian perselisihan Pemilukada, secara teoritis Hakim MK dalam pertimbangannya, lebih condong menggunakan jenis penafsiran Kontekstualisasi nilai-nilai dasar (non original intent) daripada jenis penafsiran tekstual atau penafsiran originalisme (original intent), sehingga terbuka ruang diskresi hakim MK begitu luas, yang berakibat mendistorsi kewenangan legislatif, terutama dalam hal hakim menciptakan dan merumuskan norma baru.

Bahwa putusan MK bersifat ultra petita yang bersifat positive legislature, menabrak atau bertentangan dengan ketentuan Pasal 64 UU No. 24 tahun 2003 Tentang Mahkamah Konstitusi. Di mana dalam Pasal 64 tersebut ditentukan tiga jenis amar putusan MK, (1) amar putusan menyatakan permohonan tidak dapat diterima, dalam hal MK berpendapat bahwa pemohon dan/atau permohonannya tidak memenuhi persyaratan; (2) amar putusan menyatakan permohonan dikabulkan, dalam hal MK berpendapat bahwa permohonan beralasan, dan (3) amar putusan menyatakan permohonan ditolak, dalam hal permohonan tidak beralasan. Dengan demikian, dalam UU MK tidak dikenal putusan ultra petita bersifat positive legislature (menciptakan norma hukum baru).

Putusan Ultra petita MK dikeluarkan atas dasar petitum subsidair pemohon yang berbunyi: "Jika hakim berpendapat lain, mohon putusan seadil-adilnya (ex aequo et bono)". Manakala pemohon mengajukan permohonan subsidair seperti tersebut, maka secara hukum dapat dianggap pemohon mengajukan kepada MK untuk mengabulkan hal yang tidak diminta atau melampaui permohonan pemohon, sepanjang putusan tersebut memberikan keadilan yang seadiladilnya. Sebagaimana diketahui bahwa tujuan hukum adalah untuk mewujudkan keadilan, menciptakan kepastian dan menjamin kemanfaatan bagi warga masyarakat, oleh karena itu hakim dalam setiap putusannya harus mencerminkan ketiga tujuan tersebut secara proporsional.

Tujuan hukum yang demikian juga termaktub dalam ketentuan Pasal 24 ayat (1), Pasal 28D ayat (1), 28H ayat 2 UUD NRI 1945 dan Pasal 45 ayat (1) Undang Undang Nomor 24 Tahun 2003 tentang Mahkamah Konstitusi. Menurut ketentuan Pasal 24 ayat 1 UUD NRI 1945 disebutkan bahwa "tujuan penyelenggaraan peradilan adalah menegakkan hukum dan keadilan", sedangkan menurut ketentuan Pasal 28D ayat 1 UUD NRI 1945 disebutkan: "setiap orang berhak atas pengakuan, jaminan, perlindungan, dan kepastian hukum yang adil serta perlakuan yang sama di hadapan hukum". Lebih lanjut menurut ketentuan Pasal 28H ayat 2 UUD NRI 1945 disebutkan: "setiap orang berhak mendapat kemudahan dan perlakuan khusus untuk memperoleh kesempatan dan manfaat yang sama guna mencapai persamaan dan keadilan". Adapun menurut ketentuan Pasal 45 ayat (1) Undang Undang Nomor 24 Tahun 2003 tentang Mahkamah Konstitusi disebutkan bahwa: "Mahkamah Konstitusi memutus perkara berdasarkan UndangUndang Dasar Negara Republik Indonesia Tahun 1945 sesuai dengan alat bukti dan keyakinan hakim". Menurut Penjelasan Pasal tersebut, yang dimaksud dengan: "keyakinan hakim adalah keyakinan hakim berdasarkan alat bukti".

Lebih lanjut dalam konteks putusan ultra petita, MK menyebut dalam rangka menegakkan keadilan substantif. Adapun yang dimaksud keadilan substantif, menurut Laporan Tahunan 2009 yang dikeluarkan oleh MK, adalah keadilan yang substansial, hakiki dan dirasakan oleh publik sebagai keadilan sesungguhnya, rasa keadilan yang diakui dan 
"hidup" dalam masyarakat. ${ }^{15}$ Dalam beberapa kesempatan, menurut Mahfud MD, terkait dengan soal keadilan substantif, banyak kalangan mempersoalkan bahwa upaya mencapai keadilan substantif sulit dilakukan karena sulit diukur atau tidak ada kriteria baku untuk menentukan apa itu keadilan substantif. Keadilan itu bersifat relatif atau nisbi, karena tergantung pandangan subyektif, berbeda dengan bunyi undang undang yang isinya menekankan unsur kepastian. Keadilan (substantif) akan terasa dan terlihat dari konstruksi hukum yang dibangun oleh hakim dengan menilai satu per satu bukti yang diajukan di persidangan untuk akhirnya sampai pada keyakinan dalam membuat putusan. ${ }^{16}$

Istilah keadilan substantif sebagaimana telah disinggung pada bagian Landasan Konseptual, seringkali dipertentangkan dengan keadilan prosedural. Dalam Black's Law Dictionary ditemukan istilah "substansial justice" (keadilan substantif) yang diartikan sebagai: " justice administered according to the rules of substantive law, not withstanding errors of procedure" 17 (keadilan yang dilaksanakan menurut hukum substantif, dengan tidak melihat kesalahan-kesalahan secara prosedural). Menurut Hari Chand, sebagaimana dikutip oleh I Dewa Gede Atmadja, Substantive justice: It refers to the substance of the matter involved in a dispute. In other words, it concerns the rights, privileges, duties, powers, liabilities, immunities or disabilities of the parties to a dispute". Secara bebas dapat diterjemahkan bahwa keadilan substantif menunjuk pada persoalan substansial dalam suatu sengketa. Dengan kata lain, berkaitan dengan hak-hak, kekhususan, kewajiban, kekuasaan, tanggunggugat, imunitas dan ketidakcakapan para

${ }^{15} \mathrm{MK}$, Mengawal Demokrasi dan Menegakkan Keadilan Substantif, Laporan Tahunan 2009, Sekretariat Jenderal dan Kepaniteraan MK, Jakarta, 2010, hlm 10.

${ }^{16}$ Mahfud MD dalam Martitah, Mahkamah Konstitusi dari Negative Lagislature ke Positive Legislature, Konpress, Jakarta, Juli 2013, hlm xvi-xvii.

${ }^{17}$ Henry Campbell Black, Black's Law Dictionary, ST Paul Minn, West Publishing Co, 1979, page 1281 pihak dalam suatu sengketa. Menurut Atmadja, tolok ukur keadilan substantif tampaknya pada prinsip "Kepatutan". Sedangkan yang dimaksud dengan "substantive law is that part of law which creates, defines, dan regulates rights, as opposed to adjective or remedial law, which prescribes method of enforcing the rights or obtaining redress for their invasion"18 (hukum substantif adalah bagian hukum yang menciptakan, menentukan dan mengatur berbagai macam hak, sebagaimana sering dilawankan dengan hukum ajektif, yaitu hukum yang mengatur cara bagaimana menegakkan hak-hak yang diatur dalam hukum substantif). Sedangkan menurut Hari Chand, sebagaimana dikutip I Dewa Gede Atmadja, procesural justice : It refers to procedures applied in settling a dispute or taking a decision". Keadilan Prosedural menunjuk pada penerapan prosedur penyelesaian sengketa atau prosedur pengambilan keputusan. Menurut Atmadja, tolok ukur keadilan prosedural adalah "ketaatan" pada hukum acara. ${ }^{19}$

Masih menurut Mahfud MD, untuk menghindari kesan MK suka dan sering melampaui ketentuan prosedural, perlu dipahami bahwa upaya MK mewujudkan keadilan substantif sebagaimana yang digelorakan, harus dibaca sebagai upaya MK untuk menegakkan keadilan dengan tidak semata-mata mengedepankan keadilan prosedural, tetapi juga keadilan substantif. Artinya, MK tak bisa lantas seenaknya mengabaikan ketentuan prosedural atau menerobos Undang Undang. Dengan menganut keadilan substantif, MK tak lantas harus keluar semena-mena dari ketentuan isi Undang-Undang. Dalam hal undang-undang sudah mengatur secara pasti dan dirasa adil, maka hakim wajib berpegang pada undangundang tersebut. MK diperbolehkan atau dimungkinkan membuat putusan yang keluar

\footnotetext{
${ }^{18}$ Ibid.

${ }^{19}$ I Dewa Gede Atmadja, Filsafat Hukum Dimensi Tematis \& Historis, Setara Press, Malang, Februari, 2013, hlm 76-77.
} 
dari undang-undang hanya jika undangundang itu 'mengerangkeng' keyakinan MK untuk menegakkan keadilan. ${ }^{20}$

Menurut Plato, keadilan dapat memberikan kebahagiaan, dalam pendapatnya Plato mengemukakan: "bahwa keadilan sebenarnya merupakan masalah "kebahagiaan" (convenience), yang berbedabeda atau bahkan saling bertentangan antara satu orang dengan orang lainnya, akhirnya keadilan hanyalah suatu bentuk kompromi. ${ }^{21}$ Bagi Plato keadilan adalah kebajikan yang mengandung keselarasan dan keseimbangan yang tidak dapat diketahui atau dijelaskan dengan argumentasi rasional. Selanjutnya Plato membagi kebajikan sebagai berikut: a) kebijaksanaan atau kearifan; b) keberanian atau keteguhan hati; c) kedisiplinan; serta keadilan. $^{22}$ Kebijaksanaan merupakan unsur yang sangat perlu dipertimbangkan oleh hakim apabila dirinya dihadapkan kasus hukum yang harus diselesaikan, dalam hal ini MK dalam putusannya harus benar-benar memberikan rasa keadilan bagi pemohon.

\section{E. KESIMPULAN}

Dasar pertimbangan MK mengeluarkan putusan bersifat ultra petita adalah: (a) pertimbangan filosofis, yakni dalam rangka menegakkan keadilan substantif dan keadilan konstitusional; serta dalam rangka mengawal nilai-nilai konstitusi sesuai spirit yang tercantum dalam nilai-nilai dasar Pancasila; (b) pertimbangan teoritis, hakim dalam menegakkan hukum dan keadilan, dapat menemukan dan menciptakan hukum, dan (c) pertimbangan yuridis terkait dengan ketentuan Pasal 24 ayat (1) UUD NRI 1945 : "kekuasaan kehakiman merupakan kekuasaan yang merdeka untuk menyelenggarakan peradilan guna menegakan hukum dan keadilan", ketentuan Pasal 45 ayat (1) UU No. 24 tahun 2003 Tentang

\footnotetext{
${ }^{20}$ Martitah, Mahkamah Konstitusi dari Negative Lagislature ke Positive Legislature, Konpress, Jakarta, Juli 2013, hlm xvi-xvii.

${ }^{21}$ Ibid, hlm. 92

${ }^{22}$ Sudarsono, Ilmu Filsafat suatu Pengantar, Rineka Cipta, Jakarta, 2001, hlm 271.
}

Mahkamah Konstitusi: "Mahkamah Konstitusi memutus perkara berdasarkan Undang Undang Dasar Negara Republik Indonesia Tahun 1945 sesuai alat bukti dan keyakinan hakim", dan ketentuan Pasal 5 ayat (1) UU No 48 Tahun 2009 Tentang Kekuasaan Kehakiman, yang mengamanatkan bahwa : "hakim dan hakim konstitusi wajib menggali, mengikuti dan memahami nilainilai hukum dan rasa keadilan yang hidup dalam masyarakat".

Adapun batas-batas kewenangan MK dalam mengeluarkan putusan bersifat ultra petita adalah (a) prinsip-prinsip negara hukum demokratis, dan (c) prinsip-prinsip peradilan merdeka dan tidak memihak, serta (d) asasasas umum penyelenggaraan negara yang baik. Dalam rangka menjalankan tugas dan wewenang, agar tidak terjadi penyalahgunaan wewenang, maka perlu dibentuk Majelis Kehormatan Hakim Konstitusi (MKHK) yang bersifat permanen sebagai manifestasi pengawasan internal dan lembaga pengawas eksternal, yakni Komisi Yudisial (KY) yang kedudukan, fungsi dan tugasnya diatur secara jelas dan tegas dalam norma UUD NRI 1945.

Mengingat yang memberikan wewenang konstitusional MK adalah MPR sebagai lembaga pembentuk dan pengubah UUD NRI 1945, maka dalam rangka pembatasan kewenangan MK dalam mengeluarkan putusan Ultra Petita perlu dilakukan amandemen lanjutan Pasal 24 C ayat 1 UUD NRI 1945 berkaitan dengan kewenangan MK, dengan usulan rumusan sebagai berikut: (1) "Putusan Mahkamah Konstitusi tidak boleh memuat amar putusan yang tidak diminta oleh pemohon atau melebihi permohonan pemohon, kecuali terhadap hal tertentu yang terkait dengan pokok permohonan; (2) Dengan memperhatikan prinsip-prinsip negara hukum demokratis, prinsip-prinsip peradilan merdeka dan tidak memihak serta asas-asas umum penyelenggaraan negara yang baik". 
DAFTAR PUSTAKA

A. Mukhtie Fadjar, Mahkamah Konstitusi dan perkembangan Hukum di Indonesia, Orasi Ilmiah Dalam Rangka Dies Natalis Universitas Brawijaya Malang ke- 47, 20 Februari 2010.

--------------, Mahkamah Konstitusi Sebagai Pengawal dan Penafsir Konstitusi: Masalah dan Tantangan, InTRANS Publising, Malang, 2010.

A.D. Belifante, Pokok Pokok Hukum Badan/Pejabat Tata Usaha Negara, Bina Cipta, Bandung, 1983.

Abdul Rasyid Thalib,Wewenangn Mahkamah Konstitusi dan Implikasinya dalam Sistem Ketatanegaraan Republik Indonesia, Citra Aditya Bakti, Bandung, 2006.

Achmad Roestandi, Etika dan Kesadaran Hukum Internalisasi Hukum dan Eksternalisasi Etika, Cetakan Pertama, Jelajah Nusa, Tangerang, 2012.

Al.Wisnubroto, Hakim Dan Peradilan Di Indonesia Dalam Beberapa Aspek Kajian, Universitas Atma jaya Yogyakarta,

Andi Hamzah, Kamus Hukum, Ghalia Indonesia, Jakarta, 1986.

Bagir Manan, Dasar Dasar Perundangundangan Indonesia, IN-HILL-Co, Jakarta, 1992.

-----------, Kekuasaan kehakiman Indonesia Dalam UU No. 4 Tahun 2004, FH UII Press, Yogyakarta, Cetakan pertama, Agustus 2007.

Bambang Widjojanto, "Negara Hukum dan Kekuasaan kehakiman : Upaya Membangun Akuntabilitas Kekuasaan Kehakiman", dalam Reformasi Peradilan dan Tanggungjawab Negara, Komisi Yudisial Republik Indonesia, 2010.

Bambang Sunggono dan Aries Harianto, Bantuan Hukum dan Hak Asasi Manusia, Mandar Maju, Bandung, 2001.
Frances Russell and Christine Loche, English Law and Language, Cassel, London, 1992.

Frederick Julius Stahl, Constirutional Government and Demokracy:Theory and Practice in Europe and America, Dalam Miriam Budihardjo, Op.Cit.

Hans Kelsen (a), (General Theory of Law and State), Teori Umum Hukum dan Negara, Alih bahasa oleh Drs Somardi, BEE Media, Jakarta, 2007.

Hans Kelsen [b], Teori Hukum Murni, DasarDasar Ilmu Hukum Normatif [Pure Theroy of Law] diterjemahkan oleh Raisul Muttaqien, Nusamedia, Bandung.

Harjono, Konstitusi Sebagai Rumah Bangsa, Sekretariat Jenderal dan Kepaniteraan Mahkamah Konstitusi, Jakarta, 2008.

Henry Campbell Black, Black's Law Dictionary, West Publishing Co., St.Paul, Minn, 1990.

I Dewa Gede Atmadja, Filsafat Hukum Dimensi Tematis \& Historis, Setara Press, Malang, Februari, 2013.

I.P.M. Ranuhandoko, BA., Terminologi Hukum Inggris- Indonesia, Sinar Grafika, Jakarta, Cetakan Ketiga, September 2003.

Indroharto, Usaha Memahami Peardilan Tata Usaha Negara, Pustaka Sinar Harapan, Jakarta, 2002.

Imam Anshori Saleh, Konsep Pengawasan Hakim, Upaya Memperkuat Kewenangan Kostitusional Komisi Yudisial dalam Pengawasan Peradilan, Setara Press, Malang, 1014.

Ismail Sunny, Pembagian Kekuasaan Negara, Aksara Baru, Jakarta, 1978.

J.G.Brouwer and A.E. Schilder, A Survey of Dutch Administrative Law, Ars aegulibri, Nijmegen, 1998.

Janedjri M. Gaffar, Demokrasi Konstitusional Praktik Ketatanegaraan Setelah Perubahan UUD 1945, Konstitusi Press, Cetakan Pertama, Oktober 2012.

Jazim Hamidi, Yurisprudensi tentang Penerapan Asas Asas Umum 
Penyelengaraan Pemerintahan yang Layak, Tata Nusa, Jakarta, 2000.

Jimly Asshiddie, Pengantar Ilmu Hukum Tata Negara, KonPress, Jakarta, Jilid I, 2003.

\section{, Hukum Tata Negara dan}

Pilar-Pilar Demokrasi, Konstitusi Press, Jakarta, 2006.

John Locke, Two Treaties of Government, New Edition, London, Everyman, 1993.

John Rawls, Teori Keadilan, Dasar-dasar Filsafat Politik Untuk Mewujudkan Kesejahteraan Sosial dalam Negara, [A Theory of Justice] diterjemahkan oleh Uzair Fauzan dan Heru Prasetyo, Pustaka Media, Yogyakarta, 2006.

K.C. Wheare, Modern Constitutions, Oxford University Press, 1966.

Koencoro Purbopranoto, Beberapa Catatan Hukum Tata Pemerintahan dan Peradilan Administrasi Negara, Alumni, Bandung, Cet IV, 1985.

Lie Oen Hoek, Hakim dan Hukum Tidak Tertulis, Dalam Cinerama Hukum, In Memoriam Prof. Djoko Soetono, S.H., tanpa penerbit.

Mahfud M.D., Hukum dan Pilar-Pilar Demokrasi, Gama Media, Yogyakarta, 1999.

Martitah, Mahkamah Konstitusi dari Negative Lagislature ke Positive Legislature, Konpress, Jakarta, Juli 2013.

Majelis Permusyawaratan Rakyat Republik Indonesia, Panduan Pemsyarakatan Undang Undang Dasar Negara Republik Indonesia Tahun 1945 dan Ketetapan Majelis Permusyawaratan Rakyat Republik Indonesia, Sekretariat Jenderal MPR RI, Jakarta, 2002.

MK, Mengawal Demokrasi dan Menegakkan Keadilan Substantif, Laporan Tahunan 2009, Sekretariat Jenderal dan Kepaniteraan MK, Jakarta, 2010.

Mochtar Kusumaatmadja, Konsep-konsep Hukum Dalam Pembangunan, Alumni, Bandung, 2002.
Moh. Mahfud M.D., Mahkamah Konstitusi Dalam Bingkai Hukum Progresif dan Keadilan Substansif, Bahan Pengantar Kuliah Umum "Hukum Progresif dan Keadilan Substantif" bagi para Dosen, Alumni, dan Mahasiswa S-2, serta S-3 Program Pascasarjana Universitas 17 Agustus 1945 Surabaya (Untag) Surabaya, 13 Februari 2010.

Moh. Mahfud MD, dkk., Constitutional Question, Alternatif Baru Pencarian keadilan Konstitusional, UB Press, Cetakan Pertama, 2010, Malang.

Moh. Mahfud MD, Hukum Tak Kunjung Tegak, Citra Aditya Bakti, Bandung, 2007.

Moh. Mahfud MD, Mahkamah Konstitusi Dalam Bingkai Hukum Progresif dan Keadilan Substantif, Bahan pengantar Kuliah Umum bagi Dosen, Alumni dan Mahasiswa S2 serta S3 Program Pasca Sarjana Universitas 17 Agustus 1945 (Untag) Surabaya pada hari Sabtu, 13 Februari 2010 di Surabaya, Jawa Timur. Montesquieu, Membatasi Kekuasaan : Telaah Mengenai Jiwa Undang Undang (Spirit of the Laws), Gramedia, Jakarta, 1993.

Muchammad Ali Safa'at, Mahkamah Konstitusi Dalam Sistem Checks and Balances, In-TRANS Publising, Malang, 2010.

Muchsin, Ikhtisar Ilmu Hukum, Iblam, Jakarta, 2005.

Munir Fuady, Dinamika Teori Hukum, Ghalia Indonesia, Bogor, 2007.

Otje Salman dan Anthon F. Susanto, Teori Hukum, Mengingat, Mengumpulkan dan membuka Kembali, Refika Aditama, 2009.

Padmo Wahyono, Konsep Yuridis Negara Hukum Indonesia, Makalah, UI Press, Jakarta, 1998.

Yayasan Lembaga Bantuan Hukum Indonesia, Fair Trial, Prinsip-Prinsip Peradilan Yang Jujur Dan Tidak Memihak, Editor Munir, Juni 1997, Jakarta. 
Peter Mahmud Marzuki, Penelitian Hukum, Prenada Media, Jakarta, Cetakan I, Desember 2005.

Philipus M Hadjon, “ Tentang Wewenang”, Yuridika, Volumen No. 5 \& 6, Tahun XII, September- Desember, 1997.

Philipus M. Hadjon dan Tatiek Sri Djamiati; Argumentasi Hukum, 2005.

Philipus M. Hadjon, Fungsi Normatif Hukum Administrasi Dalam mewujudkan Pemerintahan Yang Bersih, Pidato Pengukuhan Guru Besar, Universitas Airlangga, Surabaya, 1994.

Prajudi Admosudirdjo, Hukum Adminstrasi Negara, Ghalia Indoensia, Cet.9, Jakarta, 1998.

R. Wiyono, Hukum Acara Peradilan Tata Usaha Negara, Sinar Grafika Offset, Cet. I, 2007.

RM. A.B. Kusuma, Lahirnya Undang Undang Dasar 1945, Badan Penerbit Fakultas Hukum Universitas Indonesia, Jakarta, 2004.

Ridwan, Hukum Administrasi Negara, UII Press, Yogyakarta, 2002.

Satjipto Raharjo (b), Hukum Progressif, Sebuah Sketsa Hukum Indonesia, Genta, Publishing, Yogyakarta, 2009.

Sekretariat Jenderal dan Kepaniteraan Mahkamah Konstitusi, Profil Mahkamah Konstitusi Republik Indonesia, Cetakan Pertama, Jakarta Oktober 2010.

Sekretariat Jenderal dan Kepaniteraan Mahkamah Konstitusi, Undang Undang Dasar Negara Republik Indonesia Tahun 1945 dan Undang Undang Republik Indonesia Nomor 24 tahun 2003 tentang Mahkamah Konstitusi, Jakarta, Cetakan Kesembilan, Nopember.

Sekretariat Jenderal dan Kepaniteraan Mahkamah KonstitusiSambutan Ketua Mahkamah Konstitusi, Moh Mahfud MD, dalam Profil Mahkamah Konstitusi Republik Indonesia, Jakarta, Cetakan Pertama, Oktober 2010.
Shidarta, Karakteristik Penalaran Hukum Dalam Konteks Keindonesiaan, CV Utomo, Bandung, 2006.

Sir W. Ivor Jhenning, The Law and The Constitution, University London Press, Ltd, Worwikle Squere, Lndon, 1960.

Sirajuddin at.all, Legislatif Drafting Dalam Pembentukan Peraturan Perundangan, Yappika, Malang, 206.

Sri Hastuti PS., "Perlindungan HAM dalam Empat Konstitusi di Indonesia", Jurnal Hukum Magister, Vol. 1 No. 1 Januari 2005, Magister Ilmu Hukum FH U11, Yogyakarta, 2005.

Sudarsono, Ilmu Filsafat suatu Pengantar, Rineka Cipta, Jakarta, 2001.

Sudikno Mertokusumo, Penemuan Hukum, Liberty, Yogyakarta, Cet. IV, 2006.

Tim Kajian Amandemen Fakultas Hukum Universitas Brawijaya, Amandemen UUD 1945 Antara Teks dan Konteks dalam Negara yang Sedang Berubah, Sinar Grafika, Jakarta, 2000.

Tim UJM FH UB, Pedoman Penyusunan Proposal Penelitian dan Penulisan Tesis dan Disertasi, Program Pasca Sarjana Fakultas hukum Universitas Brawijaya, Universitas Brawijaya Press (UB Press), Malang, Cetakan Pertama, 2010.

Yayasan Lembaga Bantuan Hukum Indonesia, Fair Trial, Prinsip-Prinsip Peradilan Yang Jujur Dan Tidak Memihak, Editor Munir, Juni 1997, Jakarta.

Yulius Stone dalam Esmi Warasih, Pranata Hukum Sebagai Telaah Sosiologi, Suryandaru Utama, Semarang, 2005. 